\title{
Intracellular Enzyme Activities and Autolytic Properties of Lactobacillus Acidophilus and Lactobacillus Gasseri
}

\author{
Tetsuya Masuda*, Ayako Hidaka, Naoko Kondo, Takako URA and Takatoshi IToH \\ Laboratory of Dairy Food Science, College of Bioresource Sciences, Nihon University, 1866 Kameino, Fujisawa-shi, Kanagawa 252- \\ 8510, Japan
}

Received April 7, 2005; Accepted October 17, 2005

\begin{abstract}
A number of fermented milk products containing Lactobacillus acidophilus and Lactobacillus gasseri are now available as probiotic products. The proteolytic, lipolytic and autolytic properties of humanderived L. acidophilus (5 strains) and $L$. gasseri $(7$ strains) were evaluated, as these factors are closely related to cell viability and flavor development in the products. All L. gasseri strains showed higher intracellular protease activities than the $L$. acidophilus strains; in contrast, lipase activities in $L$. gasseri were mostly lower than those of $L$. acidophilus. The many strains of $L$. gasseri were shown to have a greater tendency than $L$. acidophilus to autolyze in dispersed solution; this liability was more distinct at lower pH values. These properties should be taken into account when bacteria are selected for production of probiotic products.
\end{abstract}

Keywords: L. acidophilus, L. gasseri, Intracellular enzymes, Autolysis, Probiotics, Protease, Lipase

\section{Introduction}

A probiotic bacterium is defined as "a microorganism that brings useful functions for the host by improving the balance of bacterial flora in the host intestine" (Fuller, 1989; Fuller, 1992). Probiotic bacteria include humanderived Bifidobacteria, Lactobacillus casei, Lactobacillus rhamnosus, and Lactobacillus acidophilus (which has been classified into six species, L. acidophilus, L. crispatus, $L$. amylovorus, L. gallinarum, L. gasseri, and L. johnsoni, often called the L. acidophilus group) (Shah, 2000). The health effects and functional properties of milk that has been fermented using these probiotic lactic acid bacteria are gradually being recognized by the consumer, and products fermented using various kinds of probiotic bacteria have already appeared on the market.

Although L. acidophilus has been reported to possess many advantages and health-giving properties compared to Bifidobacteria, the growth of L. acidophilus in milk is slow (Itoh et al., 1991). Many commercialized fermented milk products containing L. acidophilus- group lactic acid bacteria are made in combination with conventional yogurt starters or by adding a concentrate of live $L$. acidophilus cells propagated and collected in advance from another broth. There were concerns that the survival rate of $L$. acidophilus cells in such products is reduced by the effect of the acid produced during the fermentation process, thus resulting in decreased probiotic effects when consumed. Up to now, many reports concerning the acid tolerance, bile tolerance and viability

E-mail: tmasuda@brs.nihon-u.ac.jp of L. acidophilus group strains in milk have attempted to select L. acidophilus strains for yogurt or cheese-making which have a greater possibility of reaching the intestine as viable cells (Prasad et al., 1998; Conway et al., 1987; Gilliland et al., 1984; Holcomb et al., 1991; Ibrahim and Bezkorovainy, 1993; Lankpauthra and Shah, 1995; Chou and Weimer, 1999; Masuda et al., 2005). There have been few reports on the effect of the enzyme activities of $L$. acidophilus strains on the flavor of fermented dairy products. If the selected strain exhibits high enzyme activity, for example by protease or lipase, the degraded protein and lipid products which are gradually generated may affect the sensory properties of the fermented products. Intracellular enzymes exuded via autolytic rupture of the cells may also cause such flavor alterations. The autolytic properties of L. gasseri were demonstrated by Yokoi et al., (2004).

In the present investigation, the intracellular protease and lipase activities and autolytic properties of humanderived L. acidophilus and L. gasseri strains, which have been widely used in the production of probiotic fermented products in Japan, were examined.

\section{Materials and methods}

Bacterial strains and culture conditions The test strains were L. acidophilus JCM1028, JCM1034, JCM1132, JCM1229, and JCM11047, and L. gasseri JCM1025, JCM 1130, JCM1131, JCM8788, JCM8789, JCM8790, and JCM 11657. All of these originated from the human intestine and were obtained from the Japan Collection of Microorganisms (Wako, Japan). All cultures were maintained in 
MRS broth (Difco Laboratories, Detroit, USA) and stored at $-80^{\circ} \mathrm{C}$. The stock cultures were subcultured twice in MRS broth before use and stored at $4^{\circ} \mathrm{C}$.

The stock cultures were inoculated into $1000 \mathrm{ml}$ of MRS broth at $5 \%(\mathrm{v} / \mathrm{v})$ and incubated at $37^{\circ} \mathrm{C}$ for $18 \mathrm{~h}$. Cells were harvested by centrifugation at $5,000 \mathrm{rpm}$ for 5 minutes and washed twice in about $80 \mathrm{ml}$ of sterile distilled water. The washed cells were freeze-dried using a FDU-1000 freeze dryer (Tokyorika, Japan).

Intracellular protease activity Freeze-dried cells (15 $\mathrm{mg}$ ) of the test strains were suspended in $1.5 \mathrm{ml}$ of $100 \mathrm{mM}$ Tris $\mathrm{HCl}$ buffer solution ( $\mathrm{pH}$ 7.0) containing $0.4 \%$ sodium azide, and were disrupted by ultrasonication using a Sonifier 250 at $4^{\circ} \mathrm{C}(20 \mathrm{~min} ; 2 \mathrm{~min} \times 10$ times with oneminute intervals; BRANSON, USA). The crude enzyme solution $(0.4 \mathrm{ml})$ from which the cell debris had been removed by centrifugation $(12,000 \mathrm{rpm}, 15 \mathrm{~min})$ was mixed with $0.4 \mathrm{ml}$ of fluorescein isothiocyanate (FITC)- labeled casein solution $(0.5 \% \mathrm{w} / \mathrm{w})$ of $\mathrm{pH} 7.0$ and allowed to react at $37^{\circ} \mathrm{C}$ for 2 hours with rotation. FITC-labeled casein was prepared according to the Twining method (Twining, 1984). After the reaction, an equal amount of $14 \%$ trichloroacetic acid solution was added and mixed, and the fluorescence of the supernatant was measured using a fluorophotometer (EX: 490 nm, EM: 522 nm; Shimadzu Corporation, Japan). A unit of protease activity was defined as the amount ( $\mu \mathrm{g}$ ) of casein hydrolyzed by $1 \mathrm{mg}$ of dry cells per hour.

Intracellular lipase activity A fat emulsion was prepared as follows: butter oil (3\% of the total volume) was mixed with $50 \mathrm{ml}$ of distilled water containing Tween 80 $(1.5 \% \mathrm{v} / \mathrm{v})$, then homogenized at $12,000 \mathrm{rpm}$ for $10 \mathrm{~min}$ using an AM-7 homogenizer (NISSEI, Japan). Freezedried bacterial cells $(50 \mathrm{mg})$, prepared as above, were

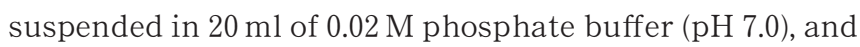
disrupted by ultrasonication. Three $\mathrm{ml}$ of the centrifuged supernatant was mixed with $15 \mathrm{ml}$ of the fat emulsion and kept at $37^{\circ} \mathrm{C}$ for 18 hours with mild shaking. An ether-ethanol $(1: 1)$ mixture $(10 \mathrm{ml})$ was added to stop the reaction, and the liberated free fatty acids were titrated with $0.02 \mathrm{M} \mathrm{NaOH}$, using three drops of $0.1 \%$ phenolphthalein solution as an indicator. A unit of lipase activity was defined as the amount $(\mu \mathrm{g})$ of free fatty acid liberated by $1 \mathrm{mg}$ of dry cells per hour.

Autolytic properties The cells of the test strains were harvested by centrifugation $\left(3,000 \mathrm{rpm}, 15 \mathrm{~min}, 5^{\circ} \mathrm{C}\right)$ from MRS broth after incubation at $37^{\circ} \mathrm{C}$ for $8 \mathrm{~h}$, and washed twice by centrifugation with sterile distilled water. The washed cells were redispersed in $5 \mathrm{ml}$ of $0.05 \mathrm{M}$ phosphate buffer ( $\mathrm{pH} 5.0$ or $\mathrm{pH} 7.0$ ) containing $0.01 \%$ sodium azide so that turbidity (at an optical density of $620 \mathrm{~nm}, 1 \mathrm{~cm}$ path length) was achieved around 0.9-1.0. The solution was kept in a water bath at $37^{\circ} \mathrm{C}$, and changes in turbidity was measured periodically after 2, 4, 6, 8 and 24 hours.

\section{Results}

The intracellular protease activities of the tested strains are compared in Fig. 1. All L. gasseri strains showed higher protease activities than the L. acidophilus

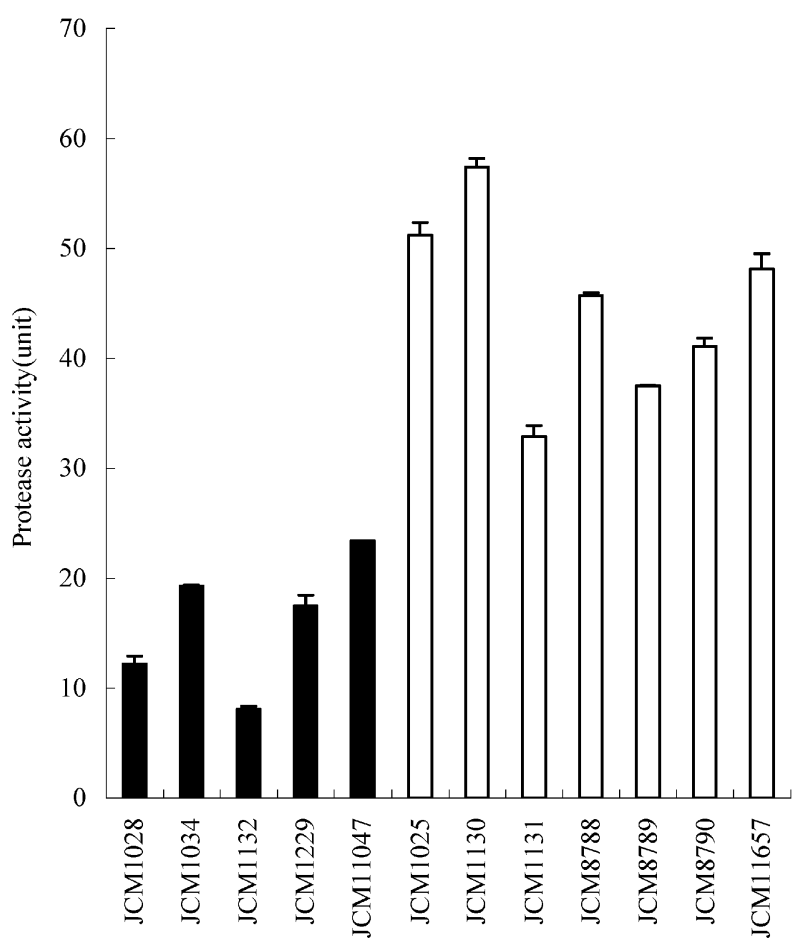

Fig. 1. Intracellular protease activities of L. acidophilus and L. gasseri using FITC-labeled casein as a substrate. 口, L. acidophilus strains; $\square$, L. gasseri strains. Data are expressed as means $( \pm \mathrm{SE})$ of triplicate measurements.

strains. In contrast, the intracellular lipase activities of L. gasseri strains, as shown in Fig. 2, were mostly lower than those of L. acidophilus.

The changes in turbidity of cells dispersed in solutions of different $\mathrm{pH}$ values are shown in Figs. 3 and 4 . The turbidity loss reflects the decrease in cells numbers by destruction through autolysis. Gradual decreases in turbidity were observed with the passage of time in all strains, and the decreases were generally more significant in L. gasseri strains than in L. acidophilus strains. Autolysis in L. gasseri strains was more distinct at pH 5.0 than at $\mathrm{pH}$ 7.0.

The results suggested that there are a number of $L$. gasseri strains that are liable to autolyze in dispersed conditions, in particular under conditions of lower $\mathrm{pH}$.

\section{Discussion}

Over the last few years in Japan, the number of fermented milk products containing L. acidophilus group lactic acid bacteria has increased. The growth of humanderived L. acidophilus group bacteria in milk is usually slow, and the flavor of products made with this strain alone is unsatisfactory. For this reason, products are often made by co-culture with conventional yogurt starter bacteria or by addition of sufficient viable cells of $L$. acidophilus group lactic acid bacteria cultured and harvested from a separate broth at the start of fermentation by yogurt bacteria. Proteolytic and lipolytic functions of co-existing probiotic bacteria affect the flavor of the products. In the case of protease, the output of exocellular protease in the early stage of fermentation was 


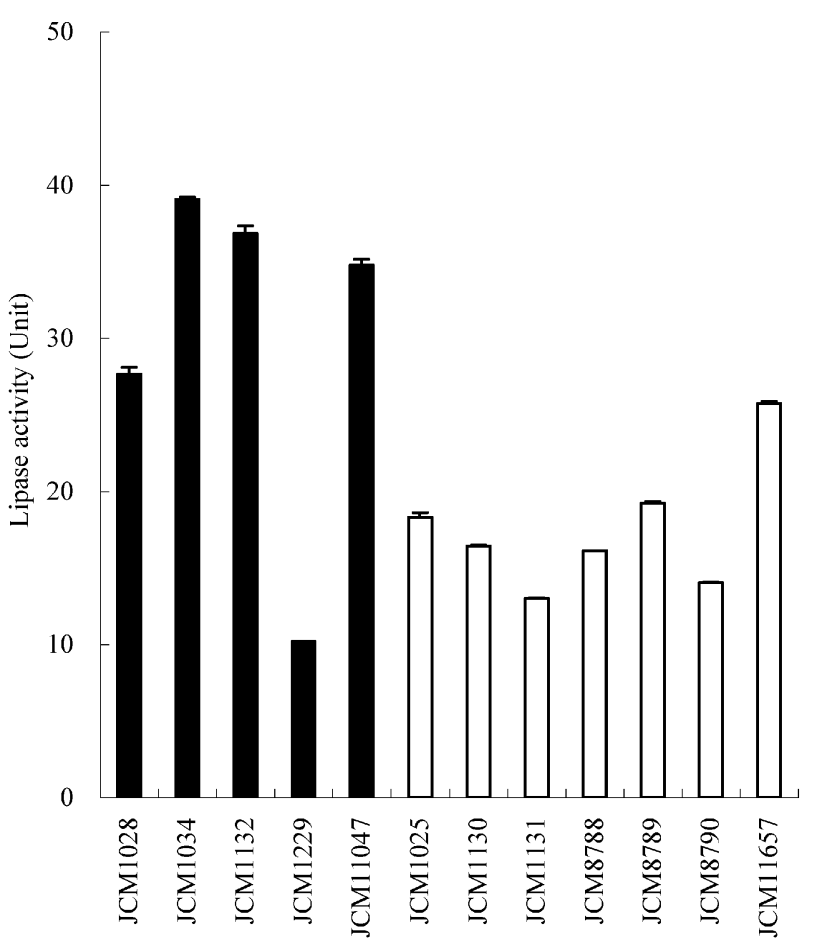

Fig. 2. Intracellular lipase activities of L. acidophilus and L. gasseri using butter oil as a substrate. $\square$, L. acidophilus strains; $\square$, L. gasseri strains. Data are expressed as means $( \pm \mathrm{SE})$ of triplicate measurements.

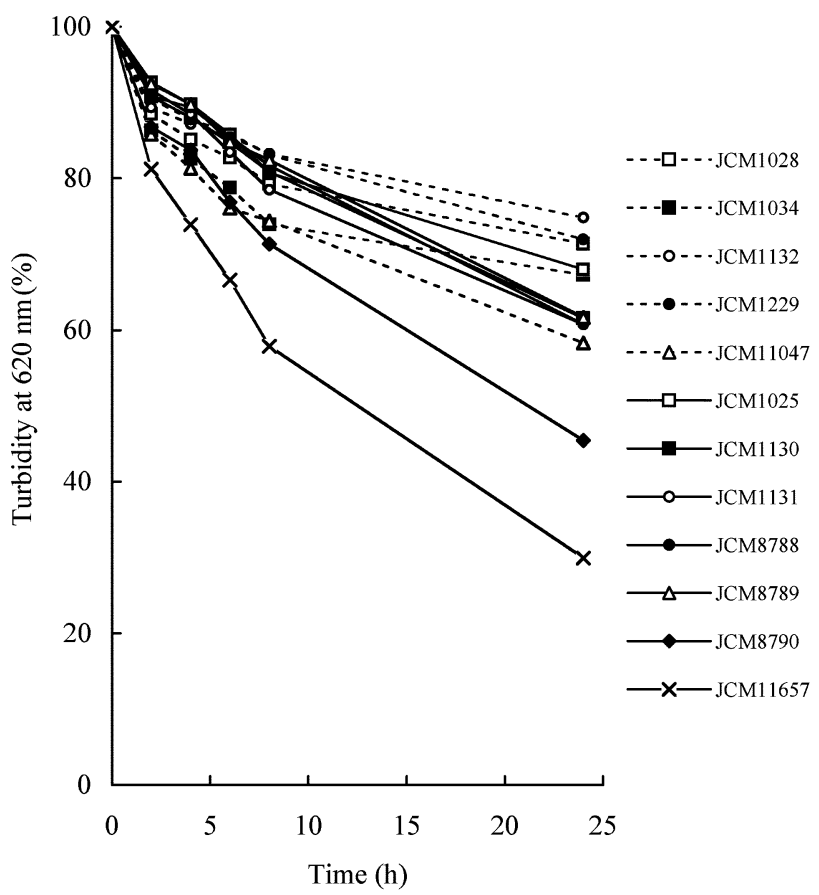

Fig. 3. Turbidity of L. acidophilus strains (--) and $L$. gasseri strains (-) dispersed in $\mathrm{pH} 7.0$ phosphate buffer at $37^{\circ} \mathrm{C}$. The bacterial cells were harvested from MRS broth after incubation at $37^{\circ} \mathrm{C}$ for $8 \mathrm{~h}$. The results are indicated in percentage of the initial turbidity. Each point represents the mean of triplicate measurements.

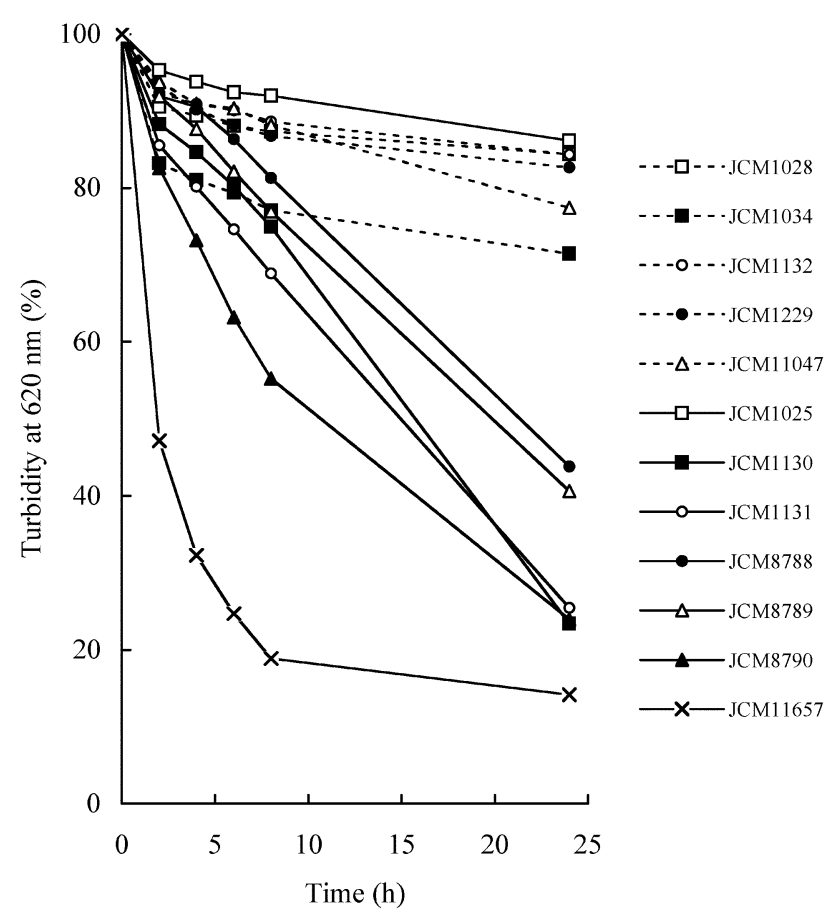

Fig. 4. Turbidity of $L$. acidophilus strains (--) and $L$. gasseri strains (-) dispersed in $\mathrm{pH} 5.0$ phosphate buffer at $37^{\circ} \mathrm{C}$. The bacterial cells were harvested from MRS broth after incubation at $37^{\circ} \mathrm{C}$ for $8 \mathrm{~h}$. The results are indicated in percentage of the initial turbidity. Each point represents the mean of triplicate measurements.

shown to be a deciding factor in whether L. acidophilus or L. gasseri could grow well in milk (Masuda et al., 2003). The release of intracellular proteases from cells will be concerned with the alternation of the flavor of the product during further fermentation and storage. Intracellular protease activities, which are compared in Fig. 1, were shown to be generally higher in L. gasseri than in $L$. acidophilus. In a previous study, we attempted to incorporate viable cells of $L$. acidophilus JCM11047 and JCM 1132 and L. gasseri JCM11657 into fresh cheese, with the aim of creating a new probiotic delivery food (Masuda $e t$ al., 2005). Different rates of protein hydrolysis were observed during storage of the products. These results indicate that intracellular protease activities should be taken into account when strains of probiotic bacteria are selected.

The lipolytic activity of lactic acid bacteria is especially important for aroma formation in fermented products. Lipase activities are known to be generally low or negligible in lactobacilli (Vogel et al., 1998; Kenneally et al., 1998). The intracellular lipase activities of the tested strains shown in Fig. 2 were strain-specific, but most of the $L$. acidophilus strains showed higher lipase activities than the L. gasseri strains, contrary to the results obtained for protease. Lipase activity is not high in either species, but is measurable in both. This should be taken into account in the consideration of flavor formation in the product.

Autolysis is observed in a variety of bacteria. The autolytic properties of lactococci used for cheese-making 
have been thoroughly investigated (Hannon et al., 2003), because the enzymes released play a key role in the development of cheese flavor. In cheese-making, cells that have a tendency to autolyze are favored, since the release of enzymes will accelerate ripening. For preparation of viable probiotics, in contrast, autolysis is unfavorable. The autolytic properties of the L. acidophilus group have been demonstrated by several researchers (Fernandez et al., 1994; Fernandez et al., 1995; Ohmiya and Sato, 1975). The likelihood of autolysis was found to vary at different $\mathrm{pH}$ values and depending on the conditions of the dispersed solutions. The results shown in Figs. 3 and 4 indicate the presence of strains that are remarkable easy to autolyze in L. acidophilus and L. gasseri. Recently, Yokoi et al., (2004) reported that autolysis was induced in L. gasseri JCM1130 and JCM1131 by infection with a prophage. We did not confirm the relationship between prophage and autolysis in the strains used. In our work, both strains showed greater autolysis at lower $\mathrm{pH}$ values, in contradiction of the results of Yokoi et al., (2004); however, the autolytic response at different $\mathrm{pH}$ values may be affected by the composition of the dispersed solution.

In conclusion, proteolytic and lipolytic properties, together with autolytic properties, should be evaluated when selecting strains of L. acidophilus and L. gasseri for probiotic purposes, because there is a close relationship between autolytic properties and the viability of the bacteria, and because enzymes released during storage affect the quality of the product.

\section{References}

Chou, L.S. and Weimer, B. (1999). Isolation and characterization of acid and bile-tolerant isolates from strains of Lactobacillus acidophilus. J. Dairy Sci., 82, 23-31.

Conway, P.L., Gorbach, S.L. and Goldin, B.R. (1987). Survival of lactic acid bacteria in the human stomach and adhesion to intestinal cells. J. Dairy Sci., 70, 1-4.

Fernandez Murga, M.L., de Ruiz Holgado, A.P. and de Valdez, G.F. (1994). Influence of $\mathrm{pH}$ on the autoly tic activity of Lactobacillus acidophilus. Microbiologie Aliments Nutrition, 12, 423-428.

Fernandez Murga, M.L., Pesce de Ruiz Holgado, A. and de Valdez, G.F. (1995). Influence of the incubation temperature on the autolytic activity of Lactobacillus acidophilus. J. Appl. Bacteriol., 78, 426-429.
Fuller, R. (1989). Probiotics in man and animals: a review. J. Appl. Bacteriol., 66, 365-378.

Fuller, R. (1992). "Probiotics - The Scientific Basis." Chapman and Hall, London.

Gilliland, S.E., Staley, T.E. and Bush, L.J. (1984). Importance of bile tolerance of Lactobacillus acidophilus used as a dietary adjunct. J. Dairy Sci., 67, 3045-3051.

Hannon, J.A., Wilkinson, M.G., Delahunty, C.M., Wallace, J.M., Morrissey, P.A. and Beresford, T.P. (2003). Use of autolytic starter systems to accelerate the ripening of Cheddar cheese. Int. Dairy J., 13, 313-323.

Holcomb, J.E., Frank, J.F. and McGregor, J.U. (1991). Viability of L. acidophilus and Bifidobacterium bifidum in soft-serve frozen yogurt. Cult. Dairy Prod. J., 26, 4-5.

Ibrahim, S.A. and Bezkorovainy, A. (1993). Inhibition of Escherichia coli by Bifidobacteria. J. Food Prot., 56, 713-715.

Itoh, T., Yamaji, A. and Nishimura, J. (1991). Improvement of growth of Lactobacillus acidophilus in whey. J. Animal Sci. Technol., 62, 314-316.

Kenneally, P.M., Leuschner, R.G. and Arendt, E.K. (1998). Evaluation of the lipolytic activity of starter culture for meat fermentation purposes. J. Appl. Microbiol., 89, 839-846.

Lankaputhra, W.E.V. and Shah, N.P. (1995). Survival of Lactobacillus acidophilus and Bifidobacterium spp. in the presence of acid and bile salts. Cult. Dairy Prod. J., 30, 2-7.

Masuda, T., Taguchi, R., Kabuki, T., Nakajima, H. and Itoh, T. (2003). Growth profile of Lactobacillus acidophilus group lactic acid bacteria in milk relating to their proteolytic activity. Milchwissenschaft, 58, 366-370.

Masuda, T., Yamanari, R. and Itoh, T. (2005). The trial for production of fresh cheese incorporated probiotic Lactobacillus acidophilus group lactic acid bacteria. Milchwissenschaft, 60, 167171.

Ohmiya, K. and Sato, Y. (1975). Promotion of autolysis in lactobacilli. Agr. Biol. Chem., 39, 585-589.

Prasad, J., Gill, H., Smart, J. and Gopal, P. K. (1998). Selection and characterization of Lactobacillus and Bifidobacterium strains for use as probiotics. Int. Dairy. J., 8, 993-1002.

Shah, N.P. (2000). Probiotic bacteria: selective enumeration and survival in dairy foods. J. Dairy Sci., 83, 894-907.

Twining, S.S. (1984). Fluorescein isothiocyanate-labeled casein assay for proteolytic enzymes. Anal. Biochem., 143, 30-34.

Vogel, R.F., Gaier, W. and Hammes, W.P. (1998). Expression of the lipase gene from Staphylococcus hyicus in Lactobacillus curvatus Lc2-c. FEMS Microbiol. Lett., 69, 289-292.

Yokoi, K., Kawasaki, K., Taketo, A. and Kodaira, K. (2004). Characterization of lytic enzyme activities of Lactobacillus gasseri with special reference to autolysis. Int. J. Food Microbiol., 96, 273-279. 